\title{
Theoretical characterization of the
}

chemical bonds of some three-membered ring compounds through QTAIM theory

\section{Darío J. R. Duarte, Margarida S. Miranda, Joaquim C. G. Esteves da Silva \& Joel F. Liebman}

\section{Structural Chemistry}

Computational and Experimental Studies of Chemical and Biological Systems

ISSN 1040-0400

Struct Chem

DOI 10.1007/s11224-015-0606-8

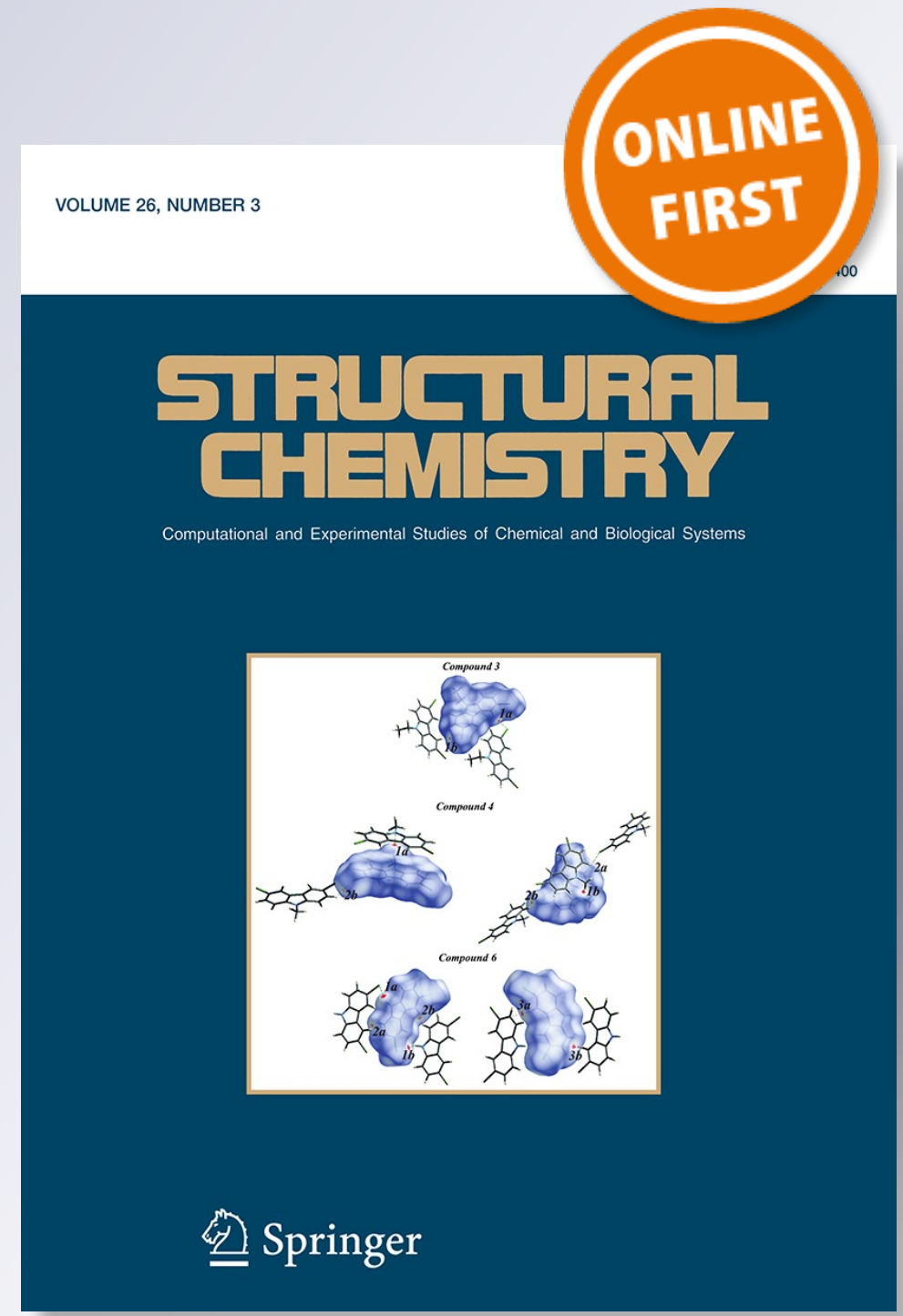

Springer 
Your article is protected by copyright and all rights are held exclusively by Springer Science +Business Media New York. This e-offprint is for personal use only and shall not be selfarchived in electronic repositories. If you wish to self-archive your article, please use the accepted manuscript version for posting on your own website. You may further deposit the accepted manuscript version in any repository, provided it is only made publicly available 12 months after official publication or later and provided acknowledgement is given to the original source of publication and a link is inserted to the published article on Springer's website. The link must be accompanied by the following text: "The final publication is available at link.springer.com". 


\title{
Theoretical characterization of the chemical bonds of some three-membered ring compounds through QTAIM theory
}

\author{
Darío J. R. Duarte ${ }^{1} \cdot$ Margarida S. Miranda ${ }^{2,4,5} \cdot$ Joaquim C. G. Esteves da Silva ${ }^{2}$. \\ Joel F. Liebman ${ }^{3}$
}

Received: 20 April 2015/Accepted: 28 May 2015

(C) Springer Science+Business Media New York 2015

\begin{abstract}
In this paper, we investigate the nature of the carbonyl and the intraring $\mathrm{C}-\mathrm{C}, \mathrm{C}-\mathrm{N}, \mathrm{C}-\mathrm{O}, \mathrm{N}-\mathrm{N}, \mathrm{O}-\mathrm{O}$ and $\mathrm{N}-\mathrm{O}$ bonds of cyclopropanone and the following cyclopropanone derivatives: aziridine-2-one (1); oxirane-2-one (2); 1,2-diaziridine-3-one (3); 1,2-dioxirane-3-one (4); 1,2oxaziridine-3-one (5); cyclopropane-1,2-dione (6); aziridine-2,3-dione (7); and oxirane-2,3-dione (8). The intramolecular distribution of the electronic charge density and the $L(\mathbf{r})=-1 / 4 \nabla^{2} \rho(\mathbf{r})$ function have been investigated within the framework of the quantum theory of atoms in molecule theory. This methodology allowed us to
\end{abstract}

Darío J. R. Duarte

djr_duarte@hotmail.com

$\bowtie$ Margarida S. Miranda

margarida.miranda@dep.uminho.pt

$\square$ Joel F. Liebman

jliebman@umbc.edu

1 Laboratorio de Estructura Molecular y Propiedades, Área de Química Física-Departamento de Química, Facultad de Ciencias Exactas y Naturales y Agrimensura, Universidad Nacional del Nordeste, Avenida Libertad 5460, 3400 Corrientes, Argentina

2 Departamento de Química e Bioquímica, Faculdade de Ciências, Centro de Investigação em Química, Universidade do Porto, Rua do Campo Alegre, s/n, 4169-007 Porto, Portugal

3 Department of Chemistry and Biochemistry, University of Maryland, Baltimore County, 1000 Hilltop Circle, Baltimore, MD 21250, USA

4 Present Address: 3B's Research Group - Biomaterials, Biodegradables and Biomimetics, University of Minho, AvePark - Parque de Ciência e Tecnologia, Zona Industrial da Gandra, 4805-017 Barco GMR, Portugal

5 ICVS/3B's - PT Government Associate Laboratory, Braga/Guimarães, Portugal characterize the bonds of cyclopropanone and the cyclopropanone derivatives studied here.

Keywords Cyclopropanone - Cyclopropanone derivatives · Electronic charge density - Laplacian . QTAIM analysis

\section{Introduction}

Cyclopropanone and its derivatives are highly reactive organic compounds containing labile bonds on a small cyclic skeleton. The chemistry of cyclopropanones is of considerable interest because of their reactivity and great potential as intermediates in organic syntheses [1, 2]. In addition, the chemistry of small-ring heterocycles as oxiranes (epoxides) and aziridines is too of interest since they are among the most widely used intermediates in organic synthesis [3-6]. Moreover, $\alpha$-lactones (oxiran-2-ones) are three-membered heterocyclic rings that have been invoked as intermediates in a variety of organic reactions [7-10]. Many of the chemical reactions of the $\alpha$-lactones have been explained by invoking a higher-energy ring-opened zwitterionic form (2). The relative stability of ring-closed form (1) versus ring-opened form (2) is dependent on the substituent R. Calculations have predicted that for the parent $\alpha$-lactone $(\mathrm{R}=\mathrm{H})$, ring-closed form (1) is significantly lower in energy than ring-opened form (2) [11-15].

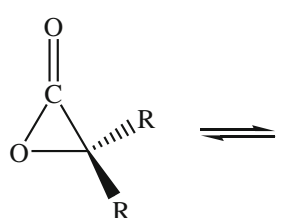

(1)

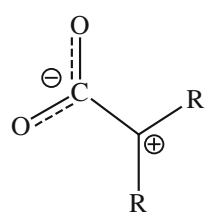

(2) 
It is well known that an exocyclic double bond increases the ring strain energy of three-membered rings carbocycles and heterocycles [16-18]. Wiberg et al. [19], through measurements of the enthalpies of combustion, estimated strain energy for methylenecyclopropane about $56 \mathrm{~kJ} \mathrm{~mol}^{-1}$ greater than that for cyclopropane. Rodriquez et al. [20] estimated that cyclopropanone is about $66 \mathrm{~kJ} \mathrm{~mol}^{-1}$ more strained than cyclopropane and calculated oxirane-2-one to have a ring strain energy $55 \mathrm{~kJ} \mathrm{~mol}^{-1}$ greater than that of oxirane (ethylene oxide). Turning to endocyclic double bonds, Johnson and Borden [17] and Wiberg et al. [19] suggested the strain energy of cyclopropene is ca. $110 \mathrm{~kJ} \mathrm{~mol}^{-1}$ more than cyclopropane, a value consonant with the results discussed by Johnson and Borden [17], and Liebman and Greenberg [21 (references cited therein)]. It is a good generalization that each trigonal carbon in a three-membered ring contributes some ca. $60 \mathrm{~kJ} \mathrm{~mol}^{-1}$.

Ruggiero et al. through the topological analysis of the electron charge density analyzed oxiranone and hydroxyoxiranone and compared them with cyclopropane, cyclopropanone and oxirane [22, 23]. They concluded that oxiranone may be considered as an $\alpha$-lactone that has considerable ionic character in the endocyclic $\mathrm{C}_{\alpha}-\mathrm{O}\left(\mathrm{C}_{1}-\right.$ $\mathrm{O}_{2}$ ) bond (see Scheme 1 for the atom numbering).

Moreover, Ho et al. [24] have investigated through the $\pi$-complex-back-donation model $(\pi$-cbd) and the quantum theory of atoms in molecules (QTAIM) the $\mathrm{C}-\mathrm{C}$ and $\mathrm{C}-\mathrm{O}$ bond lengths in oxirane and derivatives. These researchers found that the shortenings of the $\mathrm{C}-\mathrm{C}$ bond in the oxirane ring and of the neighboring $\mathrm{C}-\mathrm{C}$ bond arise mainly from the substituent groups. However, neither the $\pi$-cbd model nor the QTAIM offer a satisfactory explanation for the elongation of the intraring $\mathrm{C}-\mathrm{O}$ bonds.

In a recent work, we have studied the structure and energetics of the related molecules: aziridine-2-one (1); oxirane-2-one (2); 1,2-diaziridine-3-one (3); 1,2-dioxirane-3-one (4); 1,2-oxaziridine-3-one (5); cyclopropane1,2-dione (6); aziridine-2,3-dione (7); and oxirane-2,3dione (8) [25]. To the best of our knowledge, the nature of the interatomic interactions in the cyclopropanone derivatives mentioned is at best poorly known. In order to assess the strength of the bonds, we have analyzed local

$$
\begin{array}{ll}
\mathrm{O}_{\mathrm{X}_{2}-\mathrm{Y}_{3}}^{\mathrm{O}_{4}} & \mathrm{X}_{3}=\mathrm{CH}_{2}, \mathrm{NH}, \mathrm{O} \text { or } \mathrm{CO}
\end{array}
$$

Scheme 1 Atom numbering scheme of the cyclopropanone derivatives topological properties at the bond critical points (BCP) within the framework of the QTAIM, comparing with the properties of conventional bonds not emphasized. This theory has recently been used to estimate ring strain energies of unsaturated rings including cycloketones [26]. In what follows, we will refer to compounds with a carbonyl group and a three-membered ring as "cyclopropanone derivatives" regardless of any heteroatom in that ring.

\section{Computational details}

The geometries of cyclopropanone derivative molecules were taken from ref. [25] and optimized again using the Møller-Plesset second-order (MP2) perturbation theory [27] with the $6-311++\mathrm{G}(2 \mathrm{~d}, 2 \mathrm{p})$ basis set. Conventional, i.e., related acyclic, molecules were used for comparison with the properties of species with unstrained covalent bonds. All of these cyclic and acyclic molecules were optimized at the same level of theory. The corresponding harmonic vibrational frequencies were computed at the same level of theory as the optimized structures. The frequency calculations found that the examined structures have no imaginary vibrational frequencies showing these species are energy minima, although not necessarily the absolute minimum [cf. species (6) is less stable than its syn- and anti-enol tautomers]. All calculations were performed with Gaussian 09 [28].

A QTAIM analysis [29-31] was carried using the AIMAll [32] software, with the electron density generated at the MP2/6-311++G(2d,2p) level of theory.

\section{Results and discussion}

The topological analysis of the electron density, $\rho(\mathbf{r})$, and its Laplacian function, $\nabla^{2} \rho(\mathbf{r})$, constitute a powerful tool to investigate the nature of the chemical bonds [29]. According to Bader theory, the presence of a bond path (BP) is a universal indicator of the existence of a bonding interaction [33]. Figure 1 shows the molecular graphs and the contour maps of $L(\mathbf{r})=-1 / 4 \nabla^{2} \rho(\mathbf{r})$ function for the molecules studied here (see Scheme 1 for the atom numbering). The parent carbocyclic cyclopropanone molecule was included for comparison between them. The expected network of BP linking pairs of neighboring nuclear attractors except in molecules (4) and (5) can be observed in Fig. 1.

The $L(\mathbf{r})$ function is particularly relevant to the present work due to the fact that its topology shows the regions of the space where the electron density is locally concentrated $[L(\mathbf{r})>0]$ or depleted $[L(\mathbf{r})<0][29,30]$. 


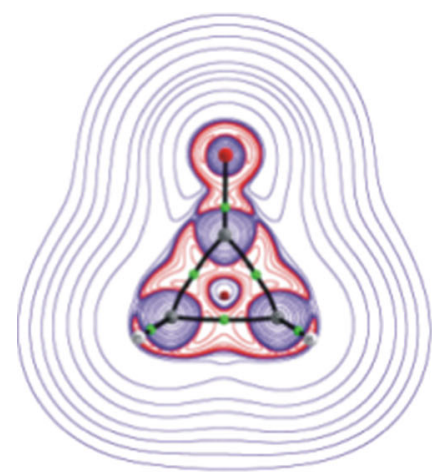

Cyclopropanone

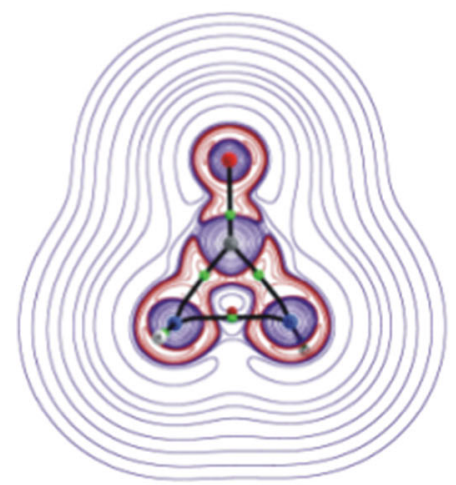

1,2-diaziridine-3-one (3)

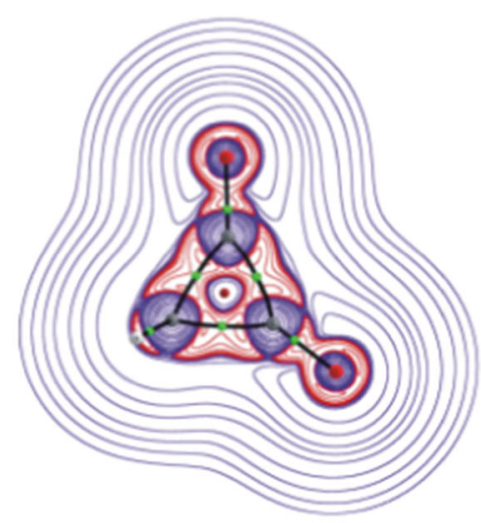

Cyclopropane-1,2-dione (6)

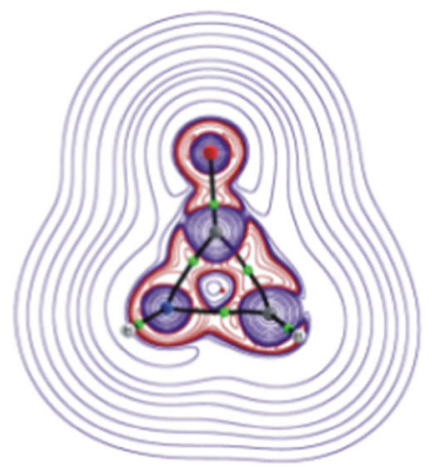

Aziridine-2-one (1)

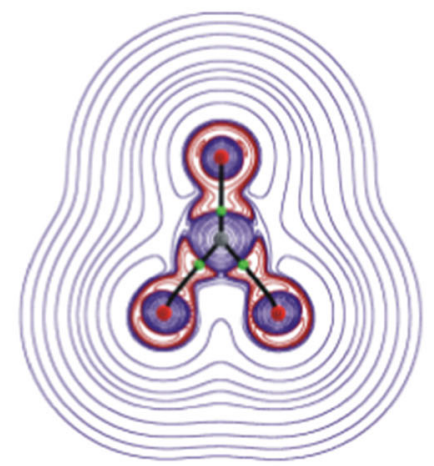

1,2-dioxirane-3-one (4)

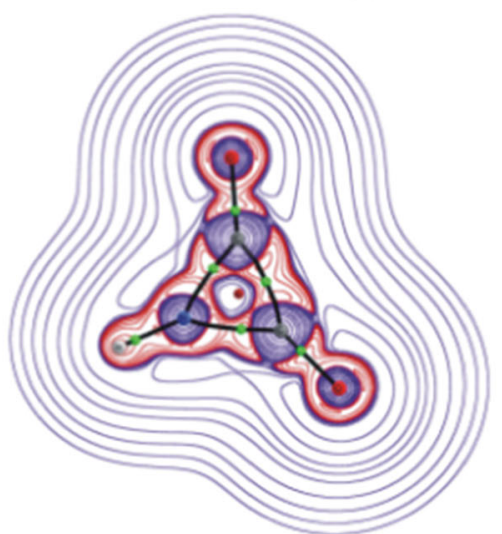

Aziridine-2,3-dione (7)

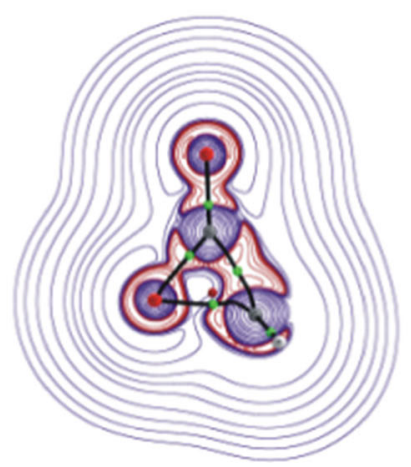

Oxirane-2-one (2)

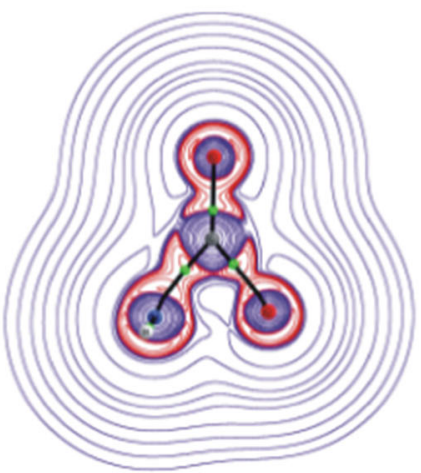

1,2-oxaziridine-3-one (5)

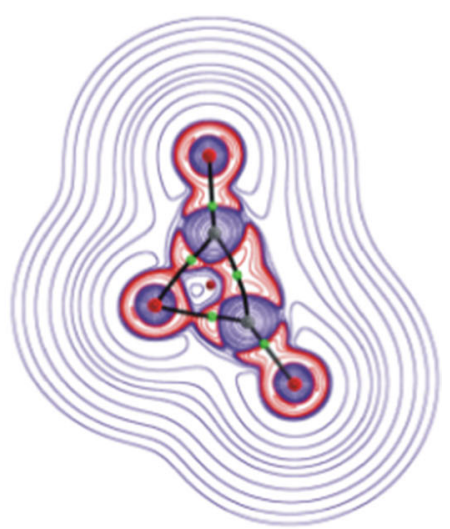

Oxirane-2,3-dione (8)

Fig. 1 Contour map of $L(\mathrm{r})=-1 / 4 \nabla^{2} \rho(\mathrm{r})$ function for the studied molecules. Blue lines denote $L(\mathrm{r})<0$ and red lines $L(\mathrm{r})>0$. The black lines indicate the bond paths, and the green and red dots indicate the $\mathrm{BCP}$ and $\mathrm{RCP}$, respectively, of the $\rho(\mathrm{r})$ topology (Color figure online)

According to QTAIM, when the electron charge density is shared by both nuclei, as is found in interactions usually characterized as covalent, these are shared-shell interactions. In these interactions, it is observed that the region of space over which the $L(\mathbf{r})$ function is positive and which contains the BCP is contiguous over the valence regions of both atoms. The second limiting of atomic interaction is when the electron charge density is not shared by both nuclei; these are the closed-shell interactions. In Fig. 1, it is observed that for all interatomic interactions $\mathrm{C}_{1}-\mathrm{O}_{4}, \mathrm{C}_{1}-\mathrm{X}_{2}$ and $\mathrm{C}_{1}-\mathrm{Y}_{3}$ the $L(\mathbf{r})$ function presents a continuous accumulation region of charge density between the interacting atoms. In other words, the $\mathrm{C}_{1}-\mathrm{O}_{4}, \mathrm{C}_{1}-\mathrm{X}_{2}$ and $\mathrm{C}_{1}-\mathrm{Y}_{3}$ interactions are covalent bonds. The $\mathrm{X}_{2}-\mathrm{Y}_{3}$ bonds are shared-shell interactions in (1), (6), (7) and (8) molecules. However, for the $\mathrm{O}_{2}-\mathrm{C}_{3}$ and $\mathrm{N}_{2}-\mathrm{N}_{3}$ bonds in molecules (2) and (3), respectively, despite not having a continuous accumulation region of charge density between the interacting nuclei, a polarization of the valence shell concentration charge (VSCC) of both atoms in direction of the bond path is observed. That is, it seems that there is a tendency to form 
continuous accumulation region of charge density between the interacting nuclei.

In other words, the $\mathrm{X}_{2}-\mathrm{Y}_{3}$ bonds in (1), (6), (7) and (8) molecules are true covalent bonds, while in (2) and (3) molecules the $\mathrm{X}_{2}-\mathrm{Y}_{3}$ bonds are very strained. Moreover, in molecules (4) and (5), it is not observed either a continuous accumulation region of charge density or a polarization of the VSCC of both atoms in direction of the $\mathrm{X}_{2}$ and $\mathrm{Y}_{3}$ nuclei. The local topological properties at the bond critical point (BCP) can be used to describe the strength of a bond, especially when the same pair of atoms is interacting. In general, the larger the magnitudes of $\rho\left(\mathbf{r}_{\mathrm{b}}\right), \nabla^{2} \rho\left(\mathbf{r}_{\mathrm{b}}\right)$ and $H\left(\mathbf{r}_{\mathrm{b}}\right)$, the stronger the bond. Table 1 reports selected local topological properties calculated at the $\mathrm{BCP}$ of the optimized molecular structures of the molecules studied here. According to QTAIM analysis, these parameters reveal the nature of the interatomic interactions. It is observed from Table 1 that all interatomic interactions $\mathrm{C}_{1}-\mathrm{O}_{4}, \mathrm{C}_{1}-\mathrm{X}_{2}$ and $\mathrm{C}_{1}-\mathrm{Y}_{3}$ present values typical of shared-shell interactions: The values of $\rho\left(\mathbf{r}_{\mathbf{b}}\right)$ are relatively large, and the values of $\nabla^{2} \rho\left(\mathbf{r}_{\mathrm{b}}\right)$ and $H\left(\mathbf{r}_{\mathrm{b}}\right)$ are relatively large and negative. That is, there are no doubts that the $\mathrm{C}_{1}-\mathrm{O}_{4}, \mathrm{C}_{1}-\mathrm{X}_{2}$ and $\mathrm{C}_{1}-\mathrm{Y}_{3}$ interactions are covalent bonds. In return, the $\mathrm{X}_{2}-\mathrm{Y}_{3}$ interactions are more complex and will be discussed later. In order to assess the strength of the bonds, next we have analyzed local topological properties at the $\mathrm{C}_{1}-\mathrm{O}_{4}, \mathrm{C}_{1}-\mathrm{X}_{2}$, $\mathrm{C}_{1}-\mathrm{Y}_{3}$ and $\mathrm{X}_{2}-\mathrm{Y}_{3} \mathrm{BCPs}$, comparing with the properties of conventional not strained covalent bonds.

\section{$\mathrm{C}_{1}-\mathrm{O}_{4}$ bond}

It can be seen that in all molecules the $\mathrm{C}_{1}-\mathrm{O}_{4}$ interatomic distance is slightly shorter than a $\mathrm{C}-\mathrm{O}$ double covalent bond and longer than a $\mathrm{C}-\mathrm{O}$ triple covalent bond. In the molecules studied here, the $\mathrm{C}-\mathrm{O}$ interatomic distances range from 1.179 to $1.207 \AA$, while $d_{\mathrm{C}=\mathrm{O}}=1.212 \AA$ in methyl acetate and $d_{\mathrm{C}-\mathrm{O}}=1.138 \AA$ in carbon monoxide.

Topological parameters $\rho\left(\mathbf{r}_{\mathrm{b}}\right)$ and $H\left(\mathbf{r}_{\mathrm{b}}\right)$ enable us to characterize the $\mathrm{C}_{1}-\mathrm{O}_{4}$ bonds. In all molecules studied here, these topological properties at the $\mathrm{C}_{1}-\mathrm{O}_{4}$ BCPs (see Table 1) are higher in magnitude than the values found in $\mathrm{C}-\mathrm{O}$ double covalent bonds [i.e., $\rho\left(\mathbf{r}_{\mathrm{b}}\right)=0.4059$ au and $H\left(\mathbf{r}_{\mathrm{b}}\right)=-0.7387 \mathrm{au}$ in acetone] and are lower in magnitude than the values found in $\mathrm{C}-\mathrm{O}$ triple covalent bonds [i.e., $\rho\left(\mathbf{r}_{\mathrm{b}}\right)=0.4935$ au and $H\left(\mathbf{r}_{\mathrm{b}}\right)=-0.9532 \mathrm{au}$ in carbon monoxide].

Moreover, the bond order $n$ of the $\mathrm{C}_{1}-\mathrm{O}_{4}$ bond has also been examined within the framework of QTAIM [29] $n=\exp \left[A \rho\left(\mathbf{r}_{\mathrm{b}}\right)-B\right]$, where $A=4.5561$ and $B=1.1523$. Surprisingly, for all molecules studied here, the bond order $n$ denotes a higher double-bond character.

Moreover, it is well known that the stretching vibration frequency is a measure of the strength of a chemical bond.
Table 1 presents stretching vibration frequency of the $\mathrm{C}_{1}-$ $\mathrm{O}_{4}$ bond in our diverse species. It is observed that the shortening of the $\mathrm{C}_{1}-\mathrm{O}_{4}$ bond, with respect to a conventional $\mathrm{C}-\mathrm{O}$ double covalent bond $\left(d_{\mathrm{C}-\mathrm{O}}=1.220 \AA\right.$ in acetone), is accompanied by an increase in the strength of the $\mathrm{C}_{1}-\mathrm{O}_{4}$ bond $\left(v_{\mathrm{C}-\mathrm{O}}=1745.15 \mathrm{~cm}^{-1}\right.$ in acetone). This idea is supported by the analysis of the bond order $n$ of the QTAIM theory. All the more, Fig. 2 shows a good correlation between the bond order and the stretch vibration frequency of the $\mathrm{C}_{1}-\mathrm{O}_{4}$ bond. The vibration frequencies of molecules (6), (7) and (8) have not been included in the correlation because they do not have a pure vibrational mode for the $\mathrm{C}_{1}-\mathrm{O}_{4}$ bond. In these molecules, there are two frequencies associated with the stretching of the $\mathrm{C}=\mathrm{O}$ bonds. It is observed that $v_{\text {strech }}$ sym is greater than $v_{\text {strech }}$ asym. These values are explained probably in terms of the coupling between the carbonyl groups and are assigned to symmetric and asymmetric stretching vibrational motions. The joint analysis of the interatomic distances, the vibrational frequencies and the local topological properties measured at the $\mathrm{C}_{1}-\mathrm{O}_{4} \mathrm{BCPs}$ show that the $\mathrm{C}_{1}-\mathrm{O}_{4}$ bonds are stronger than a conventional $\mathrm{C}-\mathrm{O}$ double bond.

\section{$\mathrm{C}_{1}-\mathrm{X}_{2}$ bond}

In molecules (1), (3), (5) and (7), the $\mathrm{C}_{1}-\mathrm{N}_{2}$ interatomic distance ranges from 1.371 to $1.414 \AA$. These values are intermediate between a single bond $\left(d_{\mathrm{C}-\mathrm{N}}=1.467 \AA\right.$ in methanamine $)$ and double bond $\left(d_{\mathrm{C}-\mathrm{N}}=1.277 \AA\right.$ in methanimine) and are on the same order of magnitude of that of the partial double bonds in formamide $\left(d_{\mathrm{C}-\mathrm{N}}=1.439 \AA\right)$.

The topological properties at the $\mathrm{C}_{1}-\mathrm{N}_{2}$ BCPs (see Table 1) show similar trends. That is, $\rho\left(\mathbf{r}_{\mathrm{b}}\right)$ and $H\left(\mathbf{r}_{\mathrm{b}}\right)$ are lower in magnitude than the values found in $\mathrm{C}-\mathrm{N}$ double covalent bonds [i.e., $\rho\left(\mathbf{r}_{\mathrm{b}}\right)=0.3935$ au and $H\left(\mathbf{r}_{\mathrm{b}}\right)=$ -0.6827 au in methanimine] and higher in magnitude than the values found in $\mathrm{C}-\mathrm{N}$ single covalent bonds [i.e., $\rho\left(\mathbf{r}_{\mathrm{b}}\right)=0.2669$ au and $H\left(\mathbf{r}_{\mathrm{b}}\right)=-0.2999$ au in methanamine]. These findings suggest that the $\mathrm{C}_{1}-\mathrm{N}_{2}$ bonds have an intermediate character between single and double bonds, despite the nonplanarity of the $\mathrm{N}_{2}$ atom in (1), (3) and (5) molecules.

\section{$\mathrm{C}_{1}-\mathrm{O}_{2} / \mathrm{O}_{3}$ bond}

In (2), (4) and (5) molecules, the $\mathrm{C}_{1}-\mathrm{O}_{2} / \mathrm{O}_{3}$ bonds are stronger than the $\mathrm{C}-\mathrm{O}$ single bond in methanol [i.e., $d_{\mathrm{C}-\mathrm{O}}=1.427 \AA, \rho\left(\mathbf{r}_{\mathrm{b}}\right)=0.2526$ au and $H\left(\mathbf{r}_{\mathrm{b}}\right)=$ $-0.3771 \mathrm{au}$ and are slightly stronger than the $\mathrm{C}-\mathrm{O}$ single bond in formic acid [i.e., $d_{\mathrm{C}-\mathrm{O}}=1.357 \AA, \rho\left(\mathbf{r}_{\mathrm{b}}\right)=$ $0.3013 \mathrm{au}$ and $H\left(\mathbf{r}_{\mathrm{b}}\right)=-0.4800 \mathrm{au}$. In molecule $(\mathbf{8})$, the $\mathrm{C}_{1}-\mathrm{O}_{2}$ bond is slightly weaker than the $\mathrm{C}-\mathrm{O}$ single bond in methanol. 
Table 1 Selected interatomic distances $(\AA)$, computed frequencies $\left(\mathrm{cm}^{-1}\right)$ and topological parameters (atomic units, except $n$ that is dimensionless)

\begin{tabular}{|c|c|c|c|c|c|c|c|}
\hline \multirow[t]{2}{*}{ Molecule } & \multirow[t]{2}{*}{ Bond } & \multirow[t]{2}{*}{$d$} & \multirow[t]{2}{*}{$v_{\text {strech }}$} & \multicolumn{4}{|c|}{ Topological parameters } \\
\hline & & & & $\rho\left(\mathbf{r}_{\mathrm{b}}\right)$ & $\nabla^{2} \rho\left(\mathbf{r}_{\mathrm{b}}\right)$ & $H\left(\mathbf{r}_{\mathrm{b}}\right)$ & $n$ \\
\hline \multirow[t]{4}{*}{ Cyclopropanone } & $\mathrm{C}_{1}-\mathrm{O}_{4}$ & 1.204 & 1877.19 & 0.4126 & -0.1835 & -0.7489 & 2.07 \\
\hline & $\mathrm{C}_{1}-\mathrm{C}_{2}$ & 1.471 & & 0.2587 & -0.5369 & -0.2305 & \\
\hline & $\mathrm{C}_{1}-\mathrm{C}_{3}$ & & & & & & \\
\hline & $\mathrm{C}_{2}-\mathrm{C}_{3}$ & 1.583 & & 0.2009 & -0.2222 & -0.1381 & \\
\hline \multirow[t]{4}{*}{1} & $\mathrm{C}_{1}-\mathrm{O}_{4}$ & 1.201 & 1913.18 & 0.4182 & -0.2682 & -0.7636 & 2.12 \\
\hline & $\mathrm{C}_{1}-\mathrm{N}_{2}$ & 1.371 & & 0.3128 & -0.8643 & -0.4026 & \\
\hline & $\mathrm{C}_{1}-\mathrm{C}_{3}$ & 1.470 & & 0.2571 & -0.5305 & -0.2284 & \\
\hline & $\mathrm{N}_{2}-\mathrm{C}_{3}$ & 1.545 & & 0.2100 & -0.1869 & -0.1707 & \\
\hline \multirow[t]{4}{*}{2} & $\mathrm{C}_{1}-\mathrm{O}_{4}$ & 1.192 & 1958.91 & 0.4287 & -0.2610 & -0.7908 & 2.23 \\
\hline & $\mathrm{C}_{1}-\mathrm{O}_{2}$ & 1.342 & & 0.3071 & -0.6093 & -0.4816 & \\
\hline & $\mathrm{C}_{1}-\mathrm{C}_{3}$ & 1.450 & & 0.2699 & -0.6225 & -0.2509 & \\
\hline & $\mathrm{O}_{2}-\mathrm{C}_{3}$ & 1.552 & & 0.1944 & 0.0212 & -0.1565 & \\
\hline \multirow[t]{4}{*}{3} & $\mathrm{C}_{1}-\mathrm{O}_{4}$ & 1.191 & 1943.26 & 0.4292 & -0.2465 & -0.7924 & 2.23 \\
\hline & $\mathrm{C}_{1}-\mathrm{N}_{2}$ & 1.393 & & 0.3032 & -0.7877 & -0.3563 & \\
\hline & $\mathrm{C}_{1}-\mathrm{N}_{3}$ & & & & & & \\
\hline & $\mathrm{N}_{2}-\mathrm{N}_{3}$ & 1.626 & & 0.1871 & 0.2946 & -0.0932 & \\
\hline \multirow[t]{4}{*}{4} & $\mathrm{C}_{1}-\mathrm{O}_{4}$ & 1.179 & 2009.95 & 0.4438 & -0.2390 & -0.8313 & 2.39 \\
\hline & $\mathrm{C}_{1}-\mathrm{O}_{2}$ & 1.342 & & 0.3105 & -0.7415 & -0.4867 & \\
\hline & $\mathrm{C}_{1}-\mathrm{O}_{3}$ & & & & & & \\
\hline & $\mathrm{O}_{2}-\mathrm{O}_{3}$ & 1.631 & & Not found & & & \\
\hline \multirow[t]{4}{*}{5} & $\mathrm{C}_{1}-\mathrm{O}_{4}$ & 1.185 & 1973.72 & 0.4364 & -0.2552 & -0.8117 & 2.31 \\
\hline & $\mathrm{C}_{1}-\mathrm{N}_{2}$ & 1.406 & & 0.2971 & -0.7611 & -0.3374 & \\
\hline & $\mathrm{C}_{1}-\mathrm{O}_{3}$ & 1.331 & & 0.3159 & -0.6725 & -0.5042 & \\
\hline & $\mathrm{N}_{2}-\mathrm{O}_{3}$ & 1.635 & & Not found & & & \\
\hline \multirow[t]{4}{*}{6} & $\mathrm{C}_{1}-\mathrm{O}_{4}$ & 1.201 & 1761.34 asym & 0.4146 & -0.1294 & -0.7552 & 2.09 \\
\hline & $\mathrm{C}_{1}-\mathrm{C}_{2}$ & 1.531 & 1841.59 sym & 0.2339 & -0.4007 & -0.1844 & \\
\hline & $\mathrm{C}_{2}-\mathrm{C}_{3}$ & & & & & & \\
\hline & $\mathrm{C}_{1}-\mathrm{C}_{3}$ & 1.494 & & 0.2454 & -0.4576 & -0.2032 & \\
\hline \multirow[t]{4}{*}{7} & $\mathrm{C}_{1}-\mathrm{O}_{4}$ & 1.192 & 1816.21 asym & 0.4268 & -0.2226 & -0.7861 & 2.21 \\
\hline & $\mathrm{C}_{1}-\mathrm{N}_{2}$ & 1.414 & 1967.67 sym & 0.2723 & -0.5988 & -0.3271 & \\
\hline & $\mathrm{C}_{1}-\mathrm{C}_{3}$ & 1.488 & & 0.2471 & -0.4414 & -0.2068 & \\
\hline & $\mathrm{N}_{2}-\mathrm{C}_{3}$ & 1.414 & & 0.2720 & -0.5969 & -0.3264 & \\
\hline \multirow[t]{4}{*}{8} & $\mathrm{C}_{1}-\mathrm{O}_{4}$ & 1.179 & 1816.45 asym & 0.4394 & -0.1025 & -0.8170 & 2.34 \\
\hline & $\mathrm{C}_{1}-\mathrm{O}_{2}$ & 1.443 & 2074.49 sym & 0.2484 & -0.3805 & -0.2930 & \\
\hline & $\mathrm{C}_{1}-\mathrm{C}_{3}$ & 1.438 & & 0.2733 & -0.6137 & -0.2547 & \\
\hline & $\mathrm{O}_{2}-\mathrm{C}_{3}$ & 1.443 & & 0.2484 & -0.3805 & -0.2930 & \\
\hline
\end{tabular}

$d$, interatomic distances; $v_{\text {strech }}$, stretching vibration frequency of the $\mathrm{C}_{1}-\mathrm{O}_{4}$ bond; $\rho\left(\mathbf{r}_{\mathrm{b}}\right)$, electron charge density; $\nabla^{2} \rho\left(\mathbf{r}_{\mathrm{b}}\right)$, Laplacian of the electron density; $H\left(\mathbf{r}_{\mathrm{b}}\right)$, electronic energy density; $n$, bond order

\section{$\mathbf{C}_{1}-\mathbf{Y}_{3}$ bond}

The $\mathrm{C}_{1}-\mathrm{C}_{3}$ bond lengths in molecules (1), (2), (6), (7) and (8) are shorter than those of a $\mathrm{C}-\mathrm{C}$ single covalent bond $\left(d_{\mathrm{C}-\mathrm{C}}=1.496 \AA\right.$ in 2-propenol). However, the topological properties $\rho\left(\mathbf{r}_{\mathrm{b}}\right)$ and $H\left(\mathbf{r}_{\mathrm{b}}\right)$ in general [except in $(\mathbf{8})$ ] are lower in magnitude than the $\mathrm{C}-\mathrm{C}$ single covalent bond [i.e., $\rho\left(\mathbf{r}_{\mathrm{b}}\right)=0.2704$ au and $H\left(\mathbf{r}_{\mathrm{b}}\right)=-0.2403$ au in 2-propenol]. That is, according to QTAIM analysis, the $\mathrm{C}_{1}-\mathrm{C}_{3}$ bond in molecules (1), (2), (6) and (7) is slightly weaker than a conventional $\mathrm{C}-\mathrm{C}$ single covalent bond, as may be expected for strained and hence destabilized species.

\section{$\mathbf{X}_{2}-\mathbf{Y}_{3}$ bond}

To the best of our knowledge, the nature of the interatomic interactions $\mathrm{X}_{2}-\mathrm{Y}_{3}$ is little known. Figure 1 clearly shows the existence of a BCP and BP for every pair $\mathrm{X}_{2}-\mathrm{Y}_{3}$ except 


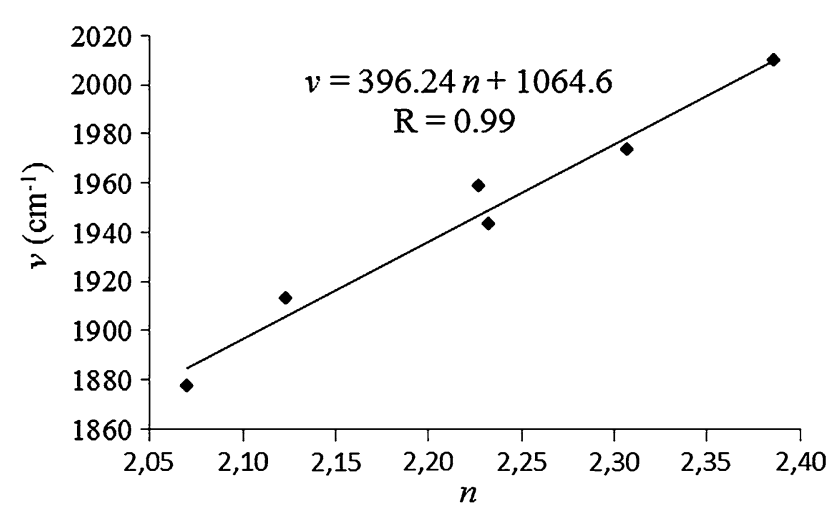

Fig. 2 Correlation between the vibrational frequencies and the bond order of the $\mathrm{C}_{1}-\mathrm{O}_{4}$ bond

for molecules (4) and (5). In molecule (1), the $\mathrm{N}_{2}-\mathrm{C}_{3}$ interatomic distance is $1.545 \AA$, being higher than the values found in $\mathrm{N}-\mathrm{C}$ single covalent bonds $\left(d_{\mathrm{N}-\mathrm{C}}=1.467 \AA\right.$ in methanamine), while in molecule (7) is $1.414 \AA$. This interatomic distance is on the same order of magnitude of that of the partial double bond in formamide $\left(d_{\mathrm{N}-\mathrm{C}}=1.430 \AA\right)$. In addition, structural analysis shows that the $\mathrm{N}_{2}$ atom in (1) has a pyramidal arrangement, while the $\mathrm{N}_{2}$ atom in (7) is planar. Concomitant with the decrease of the $\mathrm{N}-\mathrm{C}$ distance, there is an increase in $\rho\left(\mathbf{r}_{\mathrm{b}}\right)$ and $H\left(\mathbf{r}_{\mathrm{b}}\right)$. In other words, the $\mathrm{N}_{2}-\mathrm{C}_{3}$ interatomic interaction in molecule (1) is a single covalent bond, somewhat unstable, while this interaction in molecule (7) has some double-bond character.

In molecule (2), the $\mathrm{O}_{2}-\mathrm{C}_{3}$ interatomic distance $(1.552 \AA)$ is longer than the $\mathrm{O}-\mathrm{C}$ interatomic distance in methanol $(1.427 \AA)$. Local topological parameters show that at the $\mathrm{O}_{2}-\mathrm{C}_{3}$ BCP $\rho\left(\mathbf{r}_{\mathbf{b}}\right)$ is relatively large, $\nabla^{2} \rho\left(\mathbf{r}_{\mathrm{b}}\right)<0$ and $H\left(\mathbf{r}_{\mathrm{b}}\right)<0$, which is indicative of a shared-shell interaction. However, these parameters are significantly lower than those in methanol [i.e., $\rho\left(\mathbf{r}_{\mathrm{b}}\right)=0.2526 \mathrm{au}, \quad \nabla^{2} \rho\left(\mathbf{r}_{\mathrm{b}}\right)=-0.4812$ au $\quad$ and $\left.H\left(\mathbf{r}_{\mathrm{b}}\right)=-0.3771 \mathrm{au}\right]$. Based on the foregoing discussion, the $\mathrm{O}_{2}-\mathrm{C}_{3}$ bond may be considered as a weak single covalent bond. These results do not agree with those reported by Ruggiero et al. [22, 23]. These researchers considered that this bond is essentially of ionic character.

The $\mathrm{N}_{2}-\mathrm{N}_{3}$ bond in $(3)(1.626 \AA)$ is longer than the $\mathrm{N}-\mathrm{N}$ bond in hydrazine $(1.481 \AA)$. Structural analysis shows that both nitrogen atoms have a pyramidal structure as in hydrazine. QTAIM analysis shows that $\nabla^{2} \rho\left(\mathbf{r}_{\mathrm{b}}\right)>0$ and $H\left(\mathbf{r}_{\mathrm{b}}\right)<0$ at the BCP of this bond, which is indicative of a closed-shell interaction, while in hydrazine both parameters are negative at the $\mathrm{N}-\mathrm{N}$ BCP. In other words, the $\mathrm{N}_{2-}$ $\mathrm{N}_{3}$ bond in (3) is weaker than a conventional $\mathrm{N}-\mathrm{N}$ bond.

In molecule (4), the distance between $\mathrm{O}_{2}$ and $\mathrm{O}_{3}$ $(1.631 \AA)$ is substantially shorter than the distances between $\mathrm{O}_{2}$ and $\mathrm{O}_{4}$, and $\mathrm{O}_{3}$ and $\mathrm{O}_{4}(2.388 \AA)$. Something similar happens in molecule (5), and the distance between $\mathrm{N}_{2}$ and $\mathrm{O}_{3}$ $\left(1.635 \AA\right.$ ) is shorter than the distance between $\mathrm{N}_{2}$ and $\mathrm{O}_{4}$ $(2.473 \AA)$. That is, it might seem that there is an attractive interaction between the atoms $\mathrm{X}_{2}$ and $\mathrm{Y}_{3}$. Moreover, in molecule (4), the distance between $\mathrm{O}_{2}$ and $\mathrm{O}_{3}$ is longer than the $\mathrm{O}-\mathrm{O}$ single covalent bond in hydrogen peroxide, 1.631 and $1.460 \AA$, respectively. Similarly the interatomic distance between $\mathrm{N}_{2}$ and $\mathrm{O}_{3}$ in molecule (5) is longer than a conventional $\mathrm{N}-\mathrm{O}$ single covalent bond as in hydroxylamine, 1.635 and $1.448 \AA$, respectively. Figure 1 shows clearly that in molecules (4) and (5) there is not a BCP and BP for every pair $\mathrm{X}_{2}-\mathrm{Y}_{3}$. Therefore, according to Bader theory, there is not a bonding interaction between these atoms [33]. Very different is the situation in the corresponding acyclic species hydrogen peroxide and hydroxylamine, respectively. The calculations of local topological properties at the $\mathrm{O}-\mathrm{O}$ BCP of the hydrogen peroxide $\left[\rho\left(\mathbf{r}_{\mathrm{b}}\right)=0.2779 \mathrm{au}, \nabla^{2} \rho\left(\mathbf{r}_{\mathrm{b}}\right)=\right.$ -0.0558 au and $\left.H\left(\mathbf{r}_{\mathrm{b}}\right)=-0.1939 \mathrm{au}\right]$ and at the N-O BCP of the hydroxylamine $\left[\rho\left(\mathbf{r}_{\mathrm{b}}\right)=0.2838 \mathrm{au}, \quad \nabla^{2} \rho\left(\mathbf{r}_{\mathrm{b}}\right)=\right.$ -0.3238 au and $H\left(\mathbf{r}_{\mathrm{b}}\right)=-0.2298 \mathrm{au}$ ] present the typical characteristics of shared-shell interactions.

The $\mathrm{C}_{1}-\mathrm{O}_{2}$ bond in molecule (4) presents similar characteristics to a $\mathrm{C}-\mathrm{O}$ single covalent bond as in methyl acetate [i.e., $d_{\mathrm{C}-\mathrm{O}}=1.353 \AA, \rho\left(\mathbf{r}_{\mathrm{b}}\right)=0.3065 \mathrm{au}$, $\nabla^{2} \rho\left(\mathbf{r}_{\mathrm{b}}\right)=-0.6532$ au and $\left.H\left(\mathbf{r}_{\mathrm{b}}\right)=-0.5027 \mathrm{au}\right]$.

In molecule (5), the $\mathrm{C}_{1}-\mathrm{N}_{2}$ bond is weaker than $\mathrm{C}-\mathrm{N}$ partial double bond in methylacetamide [i.e., $d_{\mathrm{C}-\mathrm{N}}=$ $1.361 \AA, \rho\left(\mathbf{r}_{\mathrm{b}}\right)=0.3325 \mathrm{au}, \nabla^{2} \rho\left(\mathbf{r}_{\mathrm{b}}\right)=-1.2202 \mathrm{au}$ and $\left.H\left(\mathbf{r}_{\mathrm{b}}\right)=-0.5247 \mathrm{au}\right]$, while the $\mathrm{C}_{1}-\mathrm{O}_{3}$ bond, as in the molecule (4), presents similar characteristic to a $\mathrm{C}-\mathrm{O}$ single covalent bond as in methyl acetate.

The $\mathrm{C}_{2}-\mathrm{C}_{3}$ interatomic distance in (6) is longer than that of the $\mathrm{C}\left(\mathrm{sp}^{2}\right)-\mathrm{C}\left(\mathrm{sp}^{3}\right)$ bond in its acyclic counterpart, the $\alpha$ dicarbonyl, propane-1,2-dione $(d=1.509 \AA)$. In addition, the topological properties $\rho\left(\mathbf{r}_{\mathrm{b}}\right), \nabla^{2} \rho\left(\mathbf{r}_{\mathrm{b}}\right)$ and $H\left(\mathbf{r}_{\mathrm{b}}\right)$ are lower in magnitude than the $\mathrm{C}\left(\mathrm{sp}^{2}\right)-\mathrm{C}\left(\mathrm{sp}^{3}\right)$ bond in propane-1,2-dione [i.e., $\quad \rho\left(\mathbf{r}_{\mathrm{b}}\right)=0.2532 \mathrm{au}, \quad \nabla^{2} \rho\left(\mathbf{r}_{\mathrm{b}}\right)=$ -0.5816 au and $H\left(\mathbf{r}_{\mathrm{b}}\right)=-0.2115 \mathrm{au}$. That is, the $\mathrm{C}_{2}-\mathrm{C}_{3}$ bond in molecule (6) is slightly weaker than a conventional $\mathrm{C}-\mathrm{C}$ single covalent bond.

A similar analysis shows that the $\mathrm{O}_{2}-\mathrm{C}_{3}$ bond in $(\mathbf{8})$ is weaker than the unstrained $\mathrm{C}-\mathrm{O}$ bond in propene-2-ol.

On the other hand, the ellipticity provides a measure not only for the $\pi$ character of a bond but also its structural stability. Substantial bond ellipticities reflect structural instability, that is, the bond can easily be ruptured [29-31, 34]. Another criterion for structural stability is the distance between a $\mathrm{BCP}$ and a ring critical point (RCP). If these two critical points coalesce, they annihilate corresponding to bond rupture and concomitant ring opening. In molecules (1), (2) and (3), the $\mathrm{X}_{2}-\mathrm{Y}_{3}$ bonds have relatively large $\varepsilon$ (0.67, 2.03 and 4.61, respectively) compared to unstrained species (e.g., $\varepsilon=0.01$ for $\mathrm{C}-\mathrm{C}$ bond in cyclohexane). In 
addition, in all these molecules, the RCP is closer to the $\mathrm{X}_{2}-\mathrm{Y}_{3}$ BCP than to the $\mathrm{C}_{1}-\mathrm{X}_{2}$ and $\mathrm{C}_{1}-\mathrm{Y}_{3}$ BCPs (see Fig. 1). These results allow us to establish that the $X_{2}-Y_{3}$ bonds in molecules (1), (2) and (3) are quite unstable.

\section{Conclusion}

In this work, a systematic theoretical study, within the QTAIM framework, was carried out to provide a description of the strength of the $\mathrm{C}_{1}-\mathrm{O}_{4}, \mathrm{C}_{1}-\mathrm{X}_{2}, \mathrm{C}_{1}-\mathrm{Y}_{3}$ and $\mathrm{X}_{2}-\mathrm{Y}_{3}$ bonds of the cyclopropanone derivatives: aziridine-2-one (1); oxirane-2-one (2); 1,2-diaziridine-3-one (3); 1,2dioxirane-3-one (4); 1,2-oxaziridine-3-one (5); cyclopropane-1,2-dione (6); aziridine-2,3-dione (7); and oxirane-2,3-dione (8). The results of this theoretical study allow us to establish the following conclusions.

1. All interatomic interactions $\mathrm{C}_{1}-\mathrm{O}_{4}, \mathrm{C}_{1}-\mathrm{X}_{2}$, and $\mathrm{C}_{1}-\mathrm{Y}_{3}$ present typical characteristics of shared-shell interactions (covalent bonding). The $\mathrm{X}_{2}-\mathrm{Y}_{3}$ bonds are sharedshell interaction in (1), (6), (7) and (8) molecules, while in molecules (2) and (3), interactions within the closed-shell regime are observed. Between the atoms $\mathrm{O}_{2}$ and $\mathrm{O}_{3}$ in (4) and the atoms $\mathrm{N}_{2}$ and $\mathrm{O}_{3}$ in (5), there is not a bonded interaction.

2. The $\mathrm{N}_{2}-\mathrm{C}_{3}, \mathrm{O}_{2}-\mathrm{C}_{3}, \mathrm{~N}_{2}-\mathrm{N}_{3}, \mathrm{C}_{2}-\mathrm{C}_{3}$ and $\mathrm{O}_{2}-\mathrm{C}_{3}$ bonds in molecules (1), (2), (3), (6) and (8), respectively, may be considered as weak single covalent bonds, while the $\mathrm{N}_{2}-\mathrm{C}_{3}$ bond in molecule (7) has some double-bond character.

3. The $\mathrm{C}_{1}-\mathrm{O}_{4}$ bond, in all molecules, is stronger than a conventional $\mathrm{C}-\mathrm{O}$ double bond. The QTAIM bond order for the $\mathrm{C}_{1}-\mathrm{O}_{4}$ bond ranges from 2.07 in (6) to 2.39 in (4). In addition, a good linear correlation was found between the bond strength (measured through the bond order) and vibrational frequencies of the $\mathrm{C}_{1}-$ $\mathrm{O}_{4}$ bond.

4. In general, the $\mathrm{C}_{1}-\mathrm{N}$ bonds are rather much stronger than the $\mathrm{C}-\mathrm{N}$ conventional single covalent bonds. In contrast, $\mathrm{C}_{1}-\mathrm{O}$ bonds are only slightly stronger than $\mathrm{C}-$ $\mathrm{O}$ conventional single covalent bonds.

5. The $\mathrm{C}_{1}-\mathrm{C}_{3}$ bond in molecules (1), (2), (6) and (7) is slightly weaker than a conventional $\mathrm{C}-\mathrm{C}$ single covalent bond.

Acknowledgments D. J. R. Duarte gratefully acknowledges the Secretaría de Ciencia y Tecnología de la Universidad Nacional del Nordeste (SECYT UNNE).

\section{References}

1. Turro NJ (1969) Cyclopropanones. Acc Chem Res 2:25-32
2. Wasserman HH, Clark GM, Turley PC (1974) Recent aspects of cyclopropanone chemistry. Top Curr Chem Forts Chem Forsch 47:73-156

3. Zwanenburg B, ten Holte P (2001) The synthetic potential of three-membered ring aza-heterocycles. Top Curr Chem 216:93-124

4. Dermer OC, Ham GE (1969) Ethylenimine and other aziridines: chemistry and applications. Academic Press, New York

5. Hoffman RV (2000) Stereospecificity in the $\alpha$-lactam (aziridinone) synthon. In: Greenberg A, Breneman CM, Liebman JF (eds) The amide linkage: structural significance in chemistry, biochemistry and materials science. Amide linkage. Wiley, New York

6. Deyrup JA (1983) Aziridines. In: Hassner A (ed) Small-ring heterocycles-part 1. Wiley, New York

7. Niwayama S, Noguchi H, Ohno M, Kobayashi S (1992) On the mechanism of the Meinwald + rearrangement of electron deficient systems. Tetrahedron Lett 34:665-668

8. Schmittel M, von Seggern H (1995) Aminium salt-initiated oxygenation of ketenes-formation of succinic anhydrides. Liebigs Ann Chem 10:1815-1821

9. Strijtveen B, Kellogg RM (1987) Evidence for $\alpha$-lactone formation in the thioacetylation of some $\alpha$-hydroxy acids with the aid of Mitsunobu-type reagent. Recl Trav Chim Pays-Bas 106:539-542

10. Adam W, Blancafort L (1996) Steric and stereoelectronic control of the mode selectivity as a function of alkene structure in the reaction with dimethyl $\alpha$-peroxylactone: cycloadducts and eneproducts versus epoxides. J Am Chem Soc 118:4778-4787

11. Liebman JF, Greenberg A (1974) Estimation by bond-additivity schemes of the relative thermodynamic stabilities of threemembered-ring systems and their open dipolar forms. J Org Chem 39:123-130

12. Chung CSC (1976) $\alpha$-Lactones: a semi-empirical SCFMO study. J Mol Struct 30:189-191

13. Antolovic D, Shiner VJ, Davidson ER (1988) Theoretical study of $\alpha$-lactone, acetoxyl diradical, and the gas-phase dissociation of the chloroacetate anion. J Am Chem Soc 110:1375-1381

14. Graul ST, Squires RR (1990) Collisional activation of intramolecular nucleophilic displacement reactions: the formation of acetolactone from dissociation of $\alpha$-haloacetate negative ions. Int J Mass Spectrom Ion Process 100:785-802

15. Wenthold PG, Squires RR (1994) Gas-phase properties and reactivity of the acetate radical anion. Determination of the $\mathrm{C}-\mathrm{H}$ bond strengths in acetic acid and acetate ion. J Am Chem Soc 116:11890-11897

16. L'abbé G (1980) Heterocyclic analogues of methylene cyclopropanes. Angew Chem Int Ed Engl 19:276-289

17. Johnson WTG, Borden WT (1997) Why are methylenecyclopropane and 1-methylcylopropene more "strained" than methylcyclopropane? J Am Chem Soc 119:5930-5933

18. Bach RD, Dmitrenko O (2006) The effect of carbonyl substitution on the strain energy of small ring compounds and their sixmember ring reference compounds. J Am Chem Soc 128:4598-4611

19. Wiberg KB, Fenoglio RA (1968) Heats of formation of $\mathrm{C}_{4} \mathrm{H}_{6}$ hydrocarbons. J Am Chem Soc 90:3395-3397

20. Rodriquez CF, Williams IH (1997) Ring strain energy and enthalpy of formation of oxiranone: an ab initio theoretical determination. J Chem Soc Perkin Trans 2(5):953-958

21. Liebman JF, Greenberg A (1976) A survey of strained organic molecules. Chem Rev 76:311-365

22. Ruggiero GD, Williams IH (2001) Oxiranones: $\alpha$-lactones or zwitterions? Insights from calculated electron density distribution analysis. J Chem Soc Perkin Trans 2(5):733-737

23. Grant Buchanan J, Charlton MH, Mahon MF, Robinson JJ, Ruggiero GD, Williams IH (2002) Experimental and 
computational studies of $\alpha$-lactones: structure and bonding in the three-membered ring. J Phys Org Chem 15:642-646

24. Ho M, Szarek WA, Smith VH (2001) Theoretical studies of unusually short bond lengths in oxirane and derivatives. J Mol Struct (Theochem) 537:253-264

25. Miranda MS, Ferreira PJO, Esteves da Silva JCG, Liebman JF (2015) Three-membered ring amides: a calculational and conceptual study of the structure and energetics of 1,2-oxaziridine-3one and aziridine-2,3-dione. Can J Chem 93:406-413

26. Bauza A, Quinonero D, Deya PM, Frontera A (2012) Estimating ring strain energies in small carbocycles by means of the Bader's theory of atoms-in-molecules. Chem Phys Lett 536:165-169

27. Møller C, Plesset MC (1934) Note on an approximation treatment for many-electron systems. Phys Rev 46:618-622

28. Frisch MJ, Trucks GW, Schlegel HB, Scuseria GE, Robb MA, Cheeseman JR, Montgomery JA Jr, Vreven T, Kudin KN, Burant JC, Millam JM, Iyengar SS, Tomasi J, Barone V, Mennucci B, Cossi M, Scalmani G, Rega N, Petersson GA, Nakatsuji H, Hada M, Ehara M, Toyota K, Fukuda R, Hasegawa J, Ishida M, Nakajima T, Honda Y, Kitao O, Nakai H, Klene M, Li X, Knox JE, Hratchian HP, Cross JB, Bakken V, Adamo C, Jaramillo J, Gomperts R, Stratmann RE, Yazyev O, Austin AJ, Cammi R, Pomelli C, Ochterski JW, Ayala PY, Morokuma K, Voth GA, Salvador P, Dannenberg JJ, Zakrzewski VG, Dapprich S, Daniels
AD, Strain MC, Farkas O, Malick DK, Rabuck AD, Raghavachari K, Foresman JB, Ortiz JV, Cui Q, Baboul AG, Clifford S, Cioslowski J, Stefanov BB, Liu G, Liashenko A, Piskorz P, Komaromi I, Martin RL, Fox DJ, Keith T, Al-Laham MA, Peng CY, Nanayakkara A, Challacombe M, Gill PMW, Johnson B, Chen W, Wong MW, Gonzalez C, Pople JA (2004) Gaussian 03, Revision E.01. Gaussian Inc., Wallingford CT

29. Bader RFW (1990) Atoms in molecules. A quantum theory. Clarendon, Oxford, Great Britain

30. Popelier P (ed) (2000) Atoms in molecules: an introduction. Prentice-Hall, Harlow, Great Britain

31. Matta CF, Boyd RJ (2007) The quantum theory of atoms in molecules: from solid state to DNA and drug design. Wiley$\mathrm{VCH}$, Weinheim

32. AIMAll (Version 11.12.19), Todd A. Keith, TK Gristmill Software, Overland Park KS, USA, 2011 (aim.tkgristmill.com)

33. Bader RFW (1998) A bond path: a universal indicator of bonded interactions. J Phys Chem A 102:7314-7323

34. Cremer D, Kraka E, Slee TS, Bader RFW, Lau CDH, NguyenDang TT, Mac Dougall PJ (1983) Description of homoaromaticity in terms of electron distributions. J Am Chem Soc 105:5069-5075 